\title{
Preparação, Caracterização e Avaliação in Vitro de Microesferas de Bupivacaína em Excesso Enantiomérico de $50 \%(\mathrm{~S} 75-\mathrm{R} 25)^{*}$
}

\section{Preparation, Characterization and in Vitro Evaluation of $50 \%$ Enantiomeric Excess Bupivacaine (S75-R25)-Loaded Microspheres*}

\author{
Pedro Paulo Tanaka, TSA', Jean Pierre Estèbe ${ }^{2}$, Richard Campos ${ }^{3}$, François Chevanne ${ }^{4}$, Pascal Le Corre ${ }^{4}$, \\ Sérgio Bernardo Tenório, TSA ${ }^{1}$, Maria Fernanda Torres ${ }^{5}$
}

\section{RESUMO}

Tanaka PP, Estèbe JP, Campos R, Chevanne F, Le Corre P, Tenório SB, Torres MF — Preparação, Caracterização e Avaliação in Vitro de Microesferas de Bupivacaína em Excesso Enantiomérico de 50\% (S75-R25).

JUSTIFICATIVA E OBJETIVOS: As microesferas podem ser utilizadas como um sistema de liberação controlada para prolongar a ação de anestésicos locais. Esse estudo teve como objetivo a preparação, caracterização e análise da liberação in vitro de microesferas de bupivacaína em excesso enantiomérico de $50 \%$ (S75-R25).

MÉTODO: As micropartículas foram preparadas utilizando o copolímero de ácido poliláctico-co-glicólico contendo bupivacaína em excesso enantiomérico de $50 \%$ pelo método spray-dryed.

RESULTADOS: A caracterização das microesferas em relação ao seu tamanho e conteúdo foram similares aos valores teóricos. $A$ liberação in vitro apresentou um padrão bifásico.

CONCLUSÕES: O processo de fabricação de microesferas contendo bupivacaína em excesso enantiomérico de $50 \%$ pelo método spray-dryed é factível de ser realizado, com resultados semeIhantes aos encontrados com microesferas de bupivacaína.

Unitermos: ANESTÉSICOS, Local: bupivacaína

\footnotetext{
*Recebido do (Received from) CET/SBA do Hospital de Clínicas da Universidade Federal do Paraná, Curitiba, $P R$

1. Professor Adjunto da Disciplina de Anestesiologia da Universidade Federal do Paraná, Visiting Associate Professor (Anesthesia Departament) Stanford University School of Medicine

2. Médico do Service d'Anesthésie et Réanimation, Hôpital Hôtel Dieu, Rennes, França

3. Mestrando do Departamento de Cirurgia da UFPr, Anestesiologista Hospital Nossa Senhora da Graças

4. Faculté des Sciences Pharmaceutiques et Biologiques, Rennes, França

5. Professora Adjunta de Anátomo-Fisiologia da Unicenp
}

Apresentado (Submitted) em 3 de janeiro de 2007

Aceito (Accepted) para publicação em 25 de setembro de 2007

Endereço para correspondência (Correspondence to):

Dr. Pedro Paulo Tanaka

435 Sheridan Avenue \#306

94306 Palo Alto, CA EUA

E-mail: tanaka@ufpr.br

(c) Sociedade Brasileira de Anestesiologia, 2007

\section{SUMMARY}

Tanaka PP, Estèbe JP, Campos R, Chevanne F, Le Corre P, Tenório SB, Torres MF - Preparation, Characterization, and in Vitro Evaluation of $50 \%$ Enantiomeric Excess Bupivacaine (S75-R25)-Loaded Microspheres.

BACKGROUND AND OBJECTIVES: Microspheres can be used as a controlled delivery system to prolong the duration of action of local anesthetics. The objective of this study was the preparation, characterization and analysis of the in vitro release of $50 \%$ enantiomeric excess bupivacaine (S75-R25)-loaded microspheres.

METHODS: Microspheres were prepared using the copolymer of polylactide-co-glycolic acid by the spray-dryed method.

RESULTS: Characterization of microspheres regarding their size and content were similar to the theoretical values. The in vitro release demonstrated a biphasic pattern.

CONCLUSIONS: Manufacturing of 50\% enantiomeric excess bupivacaine-loaded microspheres by the spray-dryed method with results similar to bupivacaine-loaded microspheres can be done.

Key Words: ANESTHETICS, Local: bupivacaine.

\section{INTRODUÇÃO}

Os anestésicos locais, tanto por sua ação periférica quanto aplicados sobre o neuroeixo, constituem importante componente no manuseio multimodal da dor aguda e de algumas condições crônicas. Além de proporcionar excelente analgesia ao repouso e ao movimento, seu uso está associado a um menor consumo de opióides e à redução de seus efeitos colaterais correlacionados ${ }^{1}$. Entretanto, na ausência de uma modalidade contínua de administração, como na analgesia controlada pelo paciente ou via cateter, os benefícios da ação dos anestésicos locais não ultrapassam seis horas quando aplicados subcutaneamente e não mais que 20 horas quando por bloqueio de nervo femoral ${ }^{2}$. Tentativas em prolongar o bloqueio por meio do uso de adjuvantes ou pelo aumento da concentração ou volume do anestésico local apresentam limitado benefício ${ }^{3}$. A melhora na administração regional de anestésico local pode ser obtida com a incorporação de sistemas de liberação prolongada como implantes ${ }^{4}$, lipossomas ${ }^{5}$, complexação de fármacos com 
ciclodextrinas ${ }^{6}$ ou micropartículas ${ }^{7}$. Entre esses sistemas, as microesferas se tornam interessantes por sua propriedade de proporcionar uma taxa de liberação prolongada e por seu menor tamanho permitir a injeção local por meio de agulha. As microesferas de solução de bupivacaína em excesso enantiomérico poderiam proporcionar uma liberação prolongada do fármaco permitindo uma maior duração de ação e menor captação para a circulação sistêmica, evitando altas concentrações plasmáticas.

Esse estudo teve como objetivo a preparação, caracterização e análise da liberação in vitro de microesferas de bupivacaína em excesso enantiomérico de 50\% (S75-R25).

\section{MÉTODO}

Essa pesquisa foi aprovada pelo Laboratório de Farmácia e Biofarmácia da Universidade de Rennes, França.

A bupivacaína em excesso enantiomérico de $50 \%$ foi encapsulada como base obtida pela precipitação em meio alcalino (hidróxido de amônia) proveniente de uma solução aquosa saturada de bupivacaína em excesso enantiomérico de $50 \%$. A pureza da base resultante da bupivacaína em excesso enantiomérico de $50 \%$ foi verificada por cromotografia líquida de alta performance por comparação com cloridrato de bupivacaína em excesso enantiomérico de 50\%. As microesferas de bupivacaína em excesso enantiomérico de $50 \%$ foram preparadas com a base da bupivacaína em excesso enantiomérico de $50 \%$ dissolvida e polímero (RG $503 \mathrm{H}$, Boehringer Ingelheim). A relação de peso dos polímeros da bupivacaína em excesso enantiomérico de $50 \%$ utilizada foi de 40-60 (peso \%). A solução foi processada pelo método de spray-dryed com uma Mini Büchi B-191 spray-dryed laboratorial (Figura 1) usando bico de $0,7 \mathrm{~mm}$. Os parâmetros do processo foram assim definidos: temperatura de entrada $\left(50^{\circ} \mathrm{C}\right)$; temperatura de saída $\left(43^{\circ} \mathrm{C}\right)$; aspirador $(100 \%)$; bomba $\left(2,5 \mathrm{~mL} \cdot \mathrm{min}^{-1}\right)$ e fluxo do spray $\left(600 \mathrm{~nL} \cdot \mathrm{h}^{-1}\right)$. As

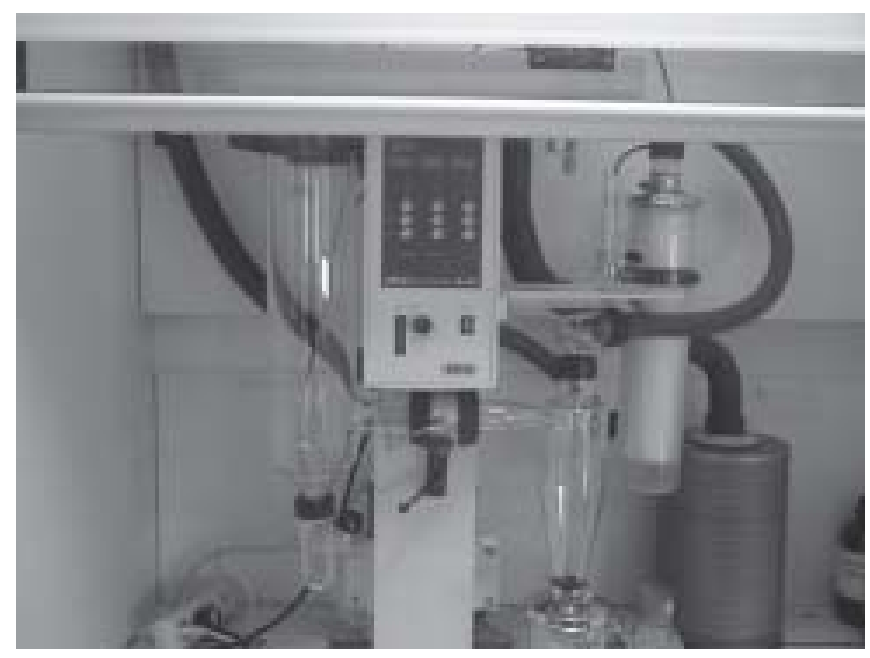

Figura 1 - Mini Büchi B-191 Spray-Dryed Laboratorial. microesferas foram armazenadas sob vácuo à temperatura de $4^{\circ} \mathrm{C}$ até caracterização.

\section{Caracterização das microesferas \\ Tamanho}

As microesferas foram dispersas em $5 \mathrm{~mL}$ de uma solução aquosa Tween 20 a 0,05\%, ultracentrifugadas por 10 segundos e depois dispersas em $75 \mathrm{~mL}$ de água destilada. Após dispersão, a distribuição do tamanho foi avaliada por cortes a laser utilizando Malvern Mastersizer S (Figura 2). Os parâmetros de distribuição dos tamanhos foram o volume do diâmetro $D(v ; 0,5)$ para $50 \%$ da amostra, a média do volume do diâmetro, $D(4,3)$ e a amplitude: $[D(v ; 0,9)$ - $D(v ; 0,1)] / D(v$; 0,5). Cada banho foi medido por três vezes.

\section{Conteúdo do medicamento}

Amostras de peso das microesferas contendo bupivacaína em excesso enantiomérico de 50\% (S75-R25; cerca de 20 $\mathrm{mg}$ ) foram dissolvidas em cloridrato de metileno (1 $\mathrm{mL})$. Então, o fármaco foi extraído em $0,1 \mathrm{~N}$ ácido sulfúrico $(5 \mathrm{~mL})$ recoberto com etidocaína como controle interno. Após mexer (5 minutos) e centrifugar (3.000 rpm, 10 minutos), $20 \mu \mathrm{L}$ da fase aquosa foram diluídos em $2 \mathrm{~mL}$ da fase móvel e $20 \mu \mathrm{L}$ dessa solução diluída foram injetados no cromatógrafo. As condições de análise da cromatografia líquida de alta performance foram as descritas previamente ${ }^{8}$. O sistema da cromatografia líquida de alta performance foi composto de uma bomba de água modelo 6000 equipada com um injetor automático de água modelo Wisp 717 e com um espectro monitor LDC Milton Roy modelo 3100, detector de comprimento de onda colocado a $205 \mathrm{~nm}$ e um integrador Delsi modelo Enica 21. As análises foram determinadas pelo uso de uma coluna $125 \times 3$ Merck Lichrospher RP-B mantida a $30^{\circ} \mathrm{C}$. A fase móvel foi uma mistura a $22: 78(\mathrm{v} / \mathrm{v})$ de acetonitrile e de solução aquosa de 0,01 $\mathrm{M} \mathrm{KH}_{2} \mathrm{PO}_{4}$, acidificada com $0,1 \% \mathrm{H}_{3} \mathrm{PO}_{4}$, a um fluxo de $0,5 \mathrm{~mL} \cdot \mathrm{min}^{-1}$.



Figura 2 - Malvern Mastersizer S. 


\section{Estudo da liberação in vitro}

O estudo de liberação foi realizado utilizando um teste de dissolução Distek modelo 5100A e um braço rotador (100 rpm) (Figura 3). O meio de liberação foi uma solução aquosa de $\mathrm{NaCl}(900 \mathrm{~mL})$, ajustada ao $\mathrm{pH}$ de 2,0 com HCl e termostato a $37^{\circ} \mathrm{C}$. Quantidades de microesferas de peso conhecido contendo bupivacaína em excesso enantiomérico de $50 \%$ (cerca de $20 \mathrm{mg}$ ) foram suspensas em $1 \mathrm{~mL}$ de solução aquosa contendo manitol a 2,5\%, carboximetilcelulose sódica a $0,75 \%$ e $0,05 \%$ de Tween 20 , contidas no meio de liberação. $O$ porcentual cumulativo da liberação da bupivacaína em excesso enantiomérico de $50 \%$ foi medido continuamente a $205 \mathrm{~nm}$, utilizando um espectofotômetro Uvikon Modelo Kontron 992 (Figura 4). Cada banho das microesferas foi analisado três vezes e os dados foram processados usando-se o sistema de dados Icalis IDIS EE software. O tempo médio de dissolução $(\mathrm{Td})$ foi derivado dos gráficos

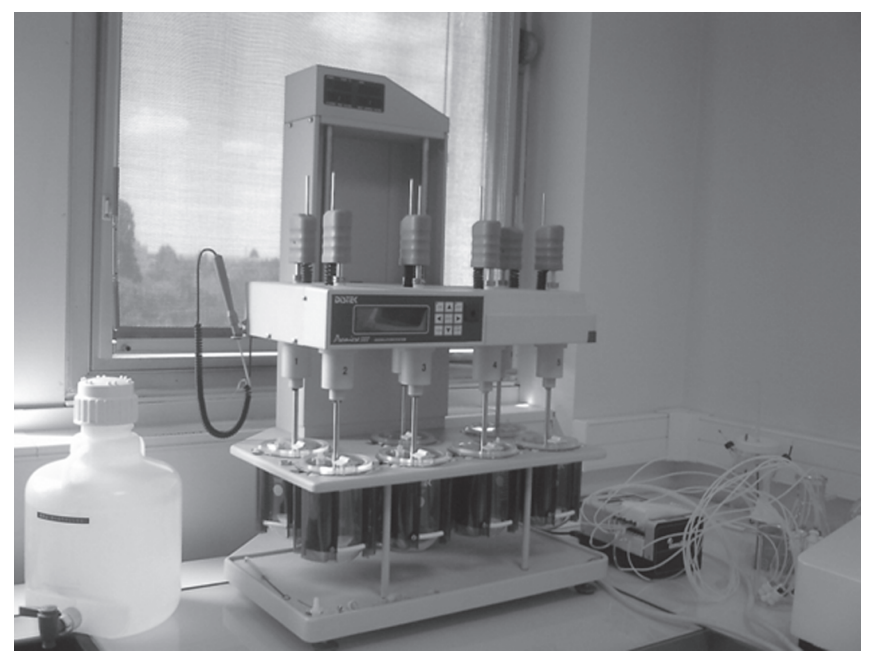

Figura 3 - Distek modelo 5100A e Braço Rotador.

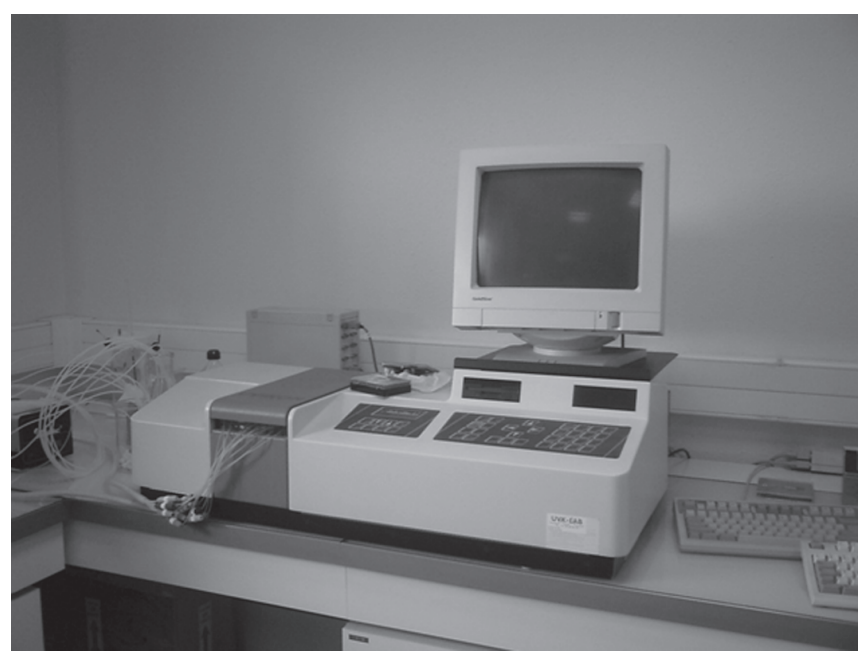

Figura 4 - Espectofotômetro Uvikon Modelo Kontron 992. porcentuais do tempo de liberação utilizando a equação de Weibull com o pacote de software da Simed SIPHAR. O mesmo processo foi repetido para um $\mathrm{pH}$ de 7,35 quando da adição de tampão de fosfato.

\section{RESULTADOS}

O tamanho médio das microesferas foi de $10,74 \mu \mathrm{m}$ (Tabela I).

Os valores do conteúdo experimental das micropartículas foram muito próximos aos valores teóricos, de acordo com a tabela II.

A composição de cada frasco contendo microesferas de bupivacaína em excesso enantiomérico de $50 \%$ para serem resuspensas em 20 mililitros de água destilada é de: Polímero RG $503 \mathrm{H}-750 \mathrm{mg}$; bupivacaína - $500 \mathrm{mg}$; manitol 1g; Twen $20-10 \mathrm{mg}$. O conteúdo teórico após resuspensão será de $3.175 \%(\mathrm{~m} / \mathrm{v})$ de uma solução de cloridrato de bupivacaína em excesso enantiomérico de $50 \%$.

O perfil da cinética de liberação in vitro das microesferas está representado na tabela III e figura 5 .

Tabela I - Diâmetro Médio das Micropartículas Liofilizadas $(\mu \mathrm{m})$

\begin{tabular}{lccc}
\hline $\mathrm{D}(\mathrm{v} ; 0,1)$ & $\mathrm{D}(\mathrm{v} ; 0,5)$ & $\mathrm{D}(\mathrm{v} ; 0,9)$ & $\mathrm{D}(4 ; 3)$ \\
0,78 & 8,80 & 23,17 & 10.74 \\
\hline
\end{tabular}



Figura 5 - Gráfico do Acúmulo de Liberação. 
Tabela II - Dados Analíticos

\begin{tabular}{lll}
\hline & Teórico & Analisado (HPLC) \\
\hline Micropartículas naturais de bupi S75-R25 & $40,0 \%(\mathrm{~m} / \mathrm{m})$ & $40,1 \%(\mathrm{~m} / \mathrm{m})$ \\
Pó liofilizado de bupi S75-R25 & $22,1 \%(\mathrm{~m} / \mathrm{m})$ & $22,1 \%(\mathrm{~m} / \mathrm{m})$ \\
\hline
\end{tabular}

Tabela III - Dados da Liberação in Vitro

\begin{tabular}{|c|c|c|c|c|c|c|c|c|}
\hline \multirow[t]{2}{*}{ Tempo (h) } & \multicolumn{8}{|c|}{ Quantidade liberada (\%) } \\
\hline & $m(n=3)$ & $\pm s$ & $m(n=3)$ & $\pm s$ & $m(n=3)$ & $\pm s$ & $m(n=3)$ & $\pm s$ \\
\hline 0 & 0,0 & 0,0 & 0,0 & 0,0 & 0,00 & 0,00 & 0,00 & 0,00 \\
\hline 1 & 7,6 & 1,2 & 8,6 & 1,6 & 5,9 & 0,3 & 6,5 & 0,7 \\
\hline 3 & 11,3 & 1,3 & 12,1 & 1,6 & 8,7 & 0,2 & 9,0 & 0,6 \\
\hline 4 & 12,6 & 1,3 & 13,3 & 1,6 & 9,8 & 0,2 & 10,0 & 0,4 \\
\hline 5 & 14,3 & 1,2 & 14,9 & 1,6 & 11,1 & 0,1 & 11,1 & 0,3 \\
\hline 6,3 & 15,8 & 1,1 & 16,8 & 1,7 & & & & \\
\hline 8 & & & & & 14,4 & 0,1 & 14,5 & 0,3 \\
\hline 8,3 & 20,7 & 1,1 & 20,7 & 1,9 & & & & \\
\hline 8,5 & & & & & 14,8 & 0,1 & 14,9 & 0,3 \\
\hline 26 & & & & & 26,1 & 0,2 & 28,6 & 3,7 \\
\hline 26,3 & 40,3 & 1,1 & 37,6 & 2,5 & & & & \\
\hline 50 & 62,9 & 3,4 & 56,9 & 3,5 & & & & \\
\hline 64 & & & & & 43,5 & 1,2 & 49,5 & 5,3 \\
\hline 70,5 & 80,4 & 0,9 & 73,4 & 4,3 & & & & \\
\hline
\end{tabular}

\section{DISCUSSÃO}

A escolha do polímero é fator importante uma vez que o mesmo deve ser biocompatível e com capacidade de armazenar boa quantidade do medicamento a ser utilizado. $O$ co-polímero de ácido poliláctico-co-glicólico (PLGA) foi escoIhido por possuir uma capacidade de cada grama poder conter até $0,8 \mathrm{~g}$ de bupivacaína e ser biodegradável ${ }^{9}$, o que não ocorre com o polímero de ácido poliláctico (PLA), que pode conter somente $22 \%$ de anestésico local, fato que em escala industrial pode tornar sua produção inviável ${ }^{7}$.

A relação ideal entre anestésico local e polímero gira entre $55 \%$ e $75 \%$, porque uma concentração acima desse valor não está associada a um bloqueio mais prolongado ${ }^{9}$. No presente estudo a relação entre bupivacaína em excesso enantiomérico de 50\% e PLGA foi de 40-60 respeitando-se os valores de formulação encontrados na literatura. A quantidade de anestésico local liberado das microesferas é crítico para assegurar o bloqueio neural adequado, requerendo que a liberação lenta mantenha a concentração terapêutica antes da eliminação do produto ${ }^{10}$.

Os valores do conteúdo de anestésico local incorporado às microesferas no presente estudo foi muito próximo aos valores teóricos para tal, indicando que a encapsulação ocorreu de maneira eficiente pelo método de spray dryed em contraste com a baixa eficiência de encapsulação obtida nos processos que utilizam evaporação ou extração do solvente com alguns polímeros ${ }^{7}$.

O perfil cinético da liberação in vitro de microesferas contendo bupivacaína em excesso enantiomérico de $50 \%$ obede- 
ceu a um padrão bifásico, ou seja, a um aumento inicial seguido de uma fase de liberação lenta. Esse perfil foi analisado em dois diferentes $\mathrm{pH}$, um ácido, o qual facilitaria a liberação do conteúdo das micropartículas, e outro mimetizando o pH humano por meio da adição de um tampão de fosfato à solução. Em comparação com as microesferas de bupivacaína preparadas de maneira semelhante ao estudo atual, o aumento inicial não foi significativo, fato que pode ser justificado pelo número pequeno de amostras (3) analisadas nesse processo ${ }^{11}$. Não obstante a isso, os resultados da avaliação in vitro desse estudo vão de encontro ao apresentado em estudo anterior que prevê a liberação de $20 \%$ do conteúdo total de bupivacaína nas primeiras 24 horas, seguida da liberação de $7 \%$ de seu conteúdo por dia até o décimo dia ${ }^{9}$. As microesferas são degradadas em monômeros que são metabolizados via ciclo de Krebs ${ }^{10}$.

Foi possível concluir que o processo de fabricação de microesferas contendo anestésico local por meio da emulsificação da bupivacaína em excesso enantiomérico de $50 \%$ com o polímero (PLGA), com a eliminação do solvente por meio do método spray-dryed e liofilização do mesmo é factível com resultados semelhantes aos encontrados com a bupivacaína.

AGRADECIMENTOS: Laboratório Cristalia pelo fornecimento do cloridrato de bupivacaína em excesso enantiomérico de $50 \%$.

\section{Preparation, Characterization and in Vitro Evaluation of $50 \%$ Enantiomeric Excess Bupivacaine (S75-R25)-Loaded Microspheres*}

Pedro Paulo Tanaka, TSA, M.D.; Jean Pierre Estèbe, M.D.; Richard Campos, M.D.; François Chevanne, M.D.; Pascal Le Corre, M.D.; Sérgio Bernardo Tenório, TSA, M.D.; Maria Fernanda Torres, M.D.

\section{INTRODUCTION}

Local anesthetics, both for their peripheral action and when applied on the neuro axis, are an important component of the multimodal management of acute pain and selected chronic conditions. Besides providing excellent analgesia at rest and during activities, their use is associated with a reduction in the consumption of opioids and, consequently, their collateral effects ${ }^{1}$. However, in the absence of a continuous mode of administration, such as patient controlled analgesia or through a catheter, the benefits of local anesthetics do not last more than 6 hours when administered subcutaneously, or more than 20 hours in the case of the femoral nerve block ${ }^{2}$. Attempts to prolong the blockade using adjuvant or increasing the concentration or the volume of the local anesthetics have limited benefits ${ }^{3}$. Regional administration of local anesthetics can be improved by incorporating slowreleasing systems, such as implants ${ }^{4}$, liposomes ${ }^{5}$, making complexes with cyclodextrin ${ }^{6}$ or using microspheres ${ }^{7}$. Among those systems, the use of microspheres is more interesting because their prolonged release rate and smaller size allow the local administration through a needle. Enantiomeric excess bupivacaine-loaded microspheres could provide prolonged release of the drug, increasing the duration of action and decreasing their transference to the systemic circulation, therefore avoiding high plasma concentrations.

The objective of this study was to prepare, characterize and analyze the in vitro release of $50 \%$ enantiomeric excess bupivacaine (S75-R25)-loaded microspheres.

\section{METHODS}

This study was approved by the Pharmaceutics and Biopharmaceutics Laboratory of the University of Rennes, France. Fifty percent enantiomeric excess bupivacaine was encapsulated as a base obtained by the precipitation in an alkaline medium (ammonia hydroxide) of an aqueous solution saturated with $50 \%$ enantiomeric excess bupivacaine. The purity of the resulting base was analyzed by high-performance liquid chromatography, comparing it with $50 \%$ enantiomeric excess bupivacaine chloride. Microspheres were prepared dissolving the $50 \%$ enantiomeric excess bupivacaine base and polymer (RG 503H, Boehringer Ingelheim). The relationship of the weight of $50 \%$ enantiomeric excess bupivacaine polymers used was 40-60 (weight \%). The solution was processed by the spray-dryed method with a laboratorial Mini Büchi B-191 (Figure 1) using a $0.7 \mathrm{~mm}$ tip. The parameters of the process were defined as follows: entrance temperature $\left(50^{\circ} \mathrm{C}\right)$; exhaust temperature $\left(43^{\circ} \mathrm{C}\right)$; aspirator $(100 \%)$; pump (2.5 mL. $\left.\mathrm{min}^{-1}\right)$; and spray flow (600 nL.h $\left.{ }^{-1}\right)$. Microspheres were stored in vacuum at a temperature of $4^{\circ} \mathrm{C}$ until characterization.

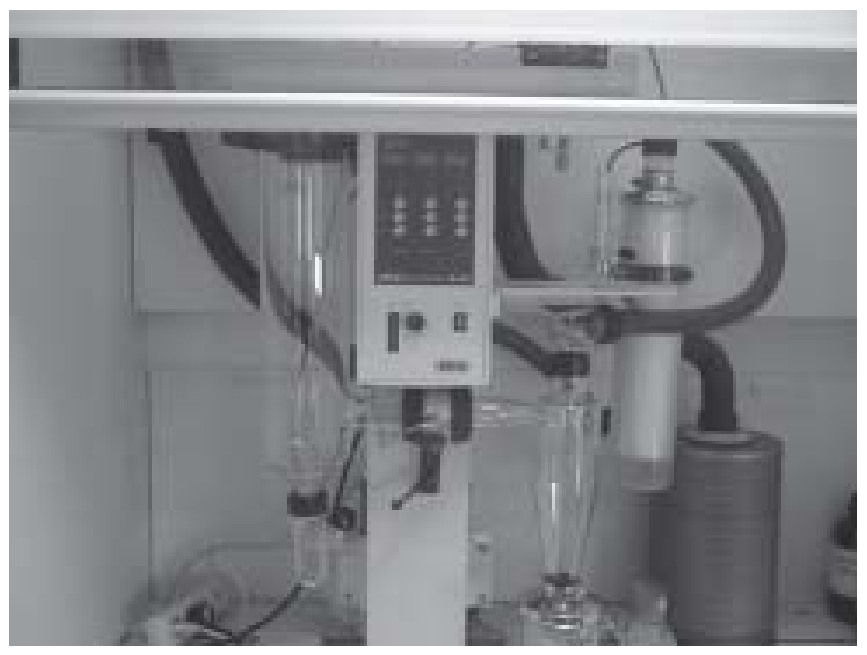

Figure 1 - Mini Büchi B-191 Spray-Dryed Laboratorial. 


\section{Characterization of microspheres}

Size

Microspheres were dispersed in $5 \mathrm{~mL}$ of an aqueous solution of $0.05 \%$ Tween 20 , ultracentrifuged by 10 seconds and then dispersed in $75 \mathrm{~mL}$ of distilled water. After dispersion, size distribution was evaluated by laser cuts using the Malvern Mastersizer S (Figure 2). Distribution parameters of the sizes were mass diameter D $(v ; 0.5)$ for $50 \%$ of the sample, mass mean diameter $D(4.3)$, and amplitude: $[D(v ; 0.9)-D(v$; $0.1)]$ / $D(v ; 0.5)$, Each bath was measured three times.



Figure 2 - Malvern Mastersizer S.

\section{Drug content}

Weight samples of $50 \%$ enantiomeric excess bupivacaineloaded microspheres (S75-R25; approximately $20 \mathrm{mg}$ ) were dissolved in methylene chloride $(1 \mathrm{~mL})$. The drug was then extracted in $0.1 \mathrm{~N}$ sulfuric acid $(5 \mathrm{~mL})$ covered with ethydocaine hydrochloride as the internal control. After mixing (5 minutes) and centrifuging (3.000 rpm, 10 minutes), $20 \mu \mathrm{L}$ of the aqueous phase were diluted in $2 \mathrm{~mL}$ of the mobile phase, and $20 \mu \mathrm{L}$ of this diluted solution were injected into the chromatograph. The conditions of the analysis of high-performance liquid chromatography have already been described ${ }^{8}$. The high-performance liquid chromatography system was composed of a model 6000 water pump equipped with a Wisp 717 automatic water injector, and a Milton Roy model 3100 spectrum LCD monitor, detector of wave length placed at $205 \mathrm{~nm}$ and a Delsi Enica 21 integrator. Analysis were determined by using a $125 \times 3$ Merck Lichrospher RP-B column maintained at $30^{\circ} \mathrm{C}$. The mobile phase was $22: 78(\mathrm{v} / \mathrm{v})$ a mixture of acetonitrile and $0.01 \mathrm{M}$ aqueous solution of $\mathrm{KH}_{2} \mathrm{PO}_{4}$ acidified with $0.1 \% \mathrm{H}_{3} \mathrm{PO}_{4}$, at a flow rate of $0.5 \mathrm{~mL} \cdot \mathrm{min}^{-1}$.

\section{Study of in vitro release}

A Distek model 5100A dissolution test and a rotator arm (100 rpm) was used for the release studies (Figure 3). The means of release was an aqueous solution of $\mathrm{NaCl}(900 \mathrm{~mL})$ adjusted to a $\mathrm{pH}$ of 2.0 with $\mathrm{HCl}$ and with the thermostat set at $37^{\circ} \mathrm{C}$. Samples of $50 \%$ enantiomeric excess bupivacaineloaded microspheres with known weight (approximately 20 $\mathrm{mg}$ ) were suspended in $1 \mathrm{~mL}$ of an aqueous solution containing $2.5 \%$ mannitol, $0.75 \%$ sodium carboxymethylcellulose, and $0.05 \%$ Tween 20 . the cumulative percentage of the release of $50 \%$ enantiomeric excess bupivacaine was measured continuously at $205 \mathrm{~nm}$ using the Uvikon Kontron Model 992 spectrophotometer (Figure 4). Each microsphere bath was analyzed three times and the data processed by the data system software Icalis IDIS EE. The mean time of dissolution (Td) was derived from percentage charts of time of release using the Weibull equation with the Simed software package SIPHAR. The same process was repeated for a $\mathrm{pH}$ of 7.35 after the addition of a phosphate buffer.

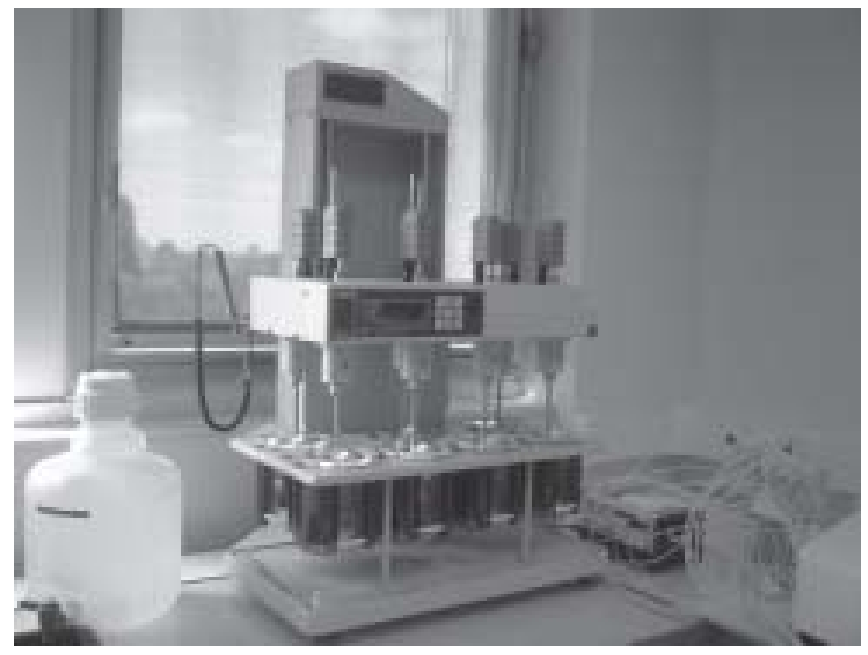

Figure 3 - Model 5100A Distek and rotator Arm.

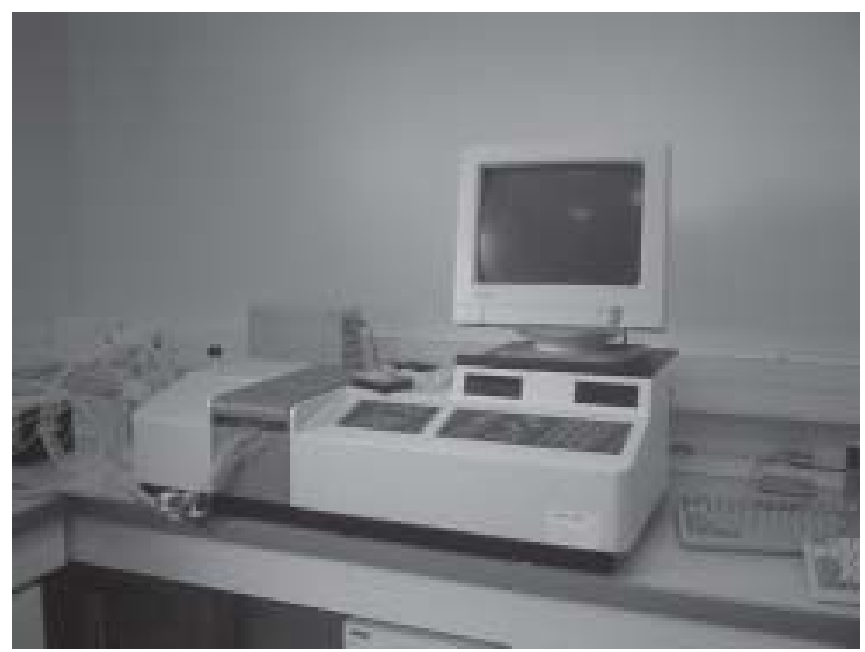

Figure 4 - Uvikon Model Kontron 992 Spectrophotometer. 


\section{RESULTS}

The mean size of the microspheres was $10.74 \mu \mathrm{m}$ (Table I). The experimental contents of the microspheres were very close to the theoretical values, according to Table II.

The composition of each vial containing 50\% enantiomeric excess bupivacaine-loaded microspheres to be suspended in 20 milliliters of distilled water is: Polimer RG $503 \mathrm{H}-750$ $\mathrm{mg}$; bupivacaine $-500 \mathrm{mg}$; mannitol $1 \mathrm{~g}$; Tween $20-10 \mathrm{mg}$. The theoretical content after resuspension will be $3.175 \%$ $(\mathrm{m} / \mathrm{v})$ of a solution containing $50 \%$ enantiomeric excess bupivacaine chloride.

Table III and Figure 5 show the kinetic profile of the in vitro release of the microspheres.

Table I - Mean Diameter of Lyophilized Particles $(\mu \mathrm{m})$

\begin{tabular}{lccc}
\hline $\mathrm{D}(\mathrm{v} ; 0.1)$ & $\mathrm{D}(\mathrm{v} ; 0.5)$ & $\mathrm{D}(\mathrm{v} ; 0.9)$ & $\mathrm{D}(4 ; 3)$ \\
0.78 & 8.80 & 23.17 & 10.74 \\
\hline
\end{tabular}

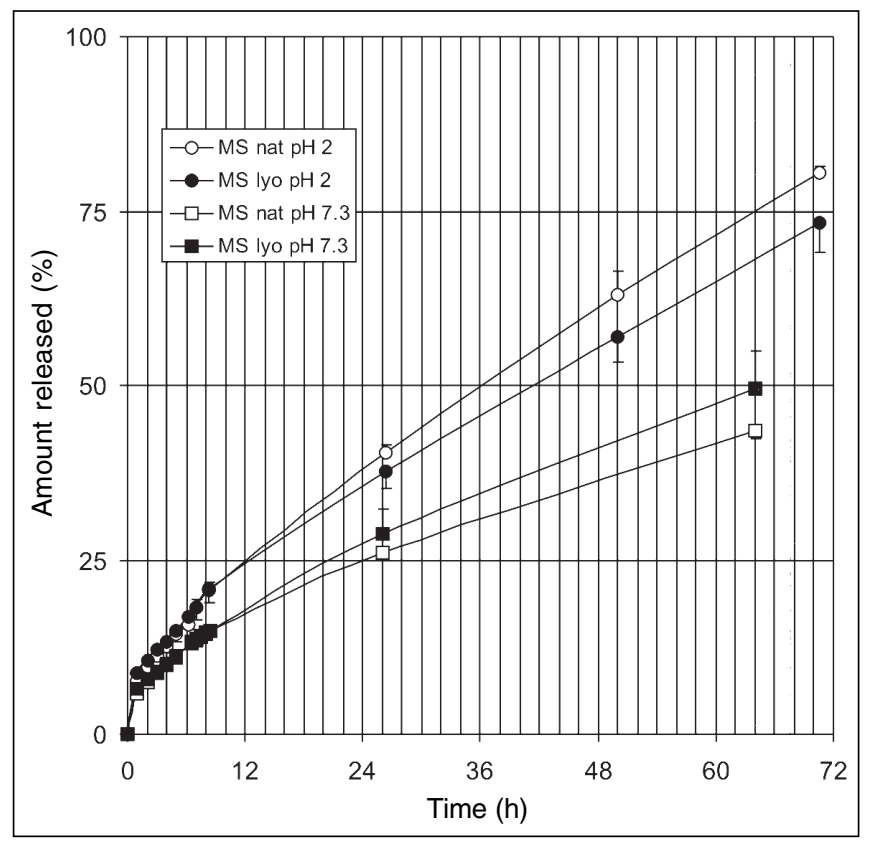

Figura 5 - Cumulative Release Chart.

Table II - Analytical Data

\begin{tabular}{lll}
\hline & Theoretical & Analyzed (HPLC) \\
\hline Natural microparticles of bupi S75-R25 & $40.0 \%(\mathrm{~m} / \mathrm{m})$ & $40.1 \%(\mathrm{~m} / \mathrm{m})$ \\
Lyophilized powder of bupi S75-R25 & $22.1 \%(\mathrm{~m} / \mathrm{m})$ & $22.1 \%(\mathrm{~m} / \mathrm{m})$ \\
\hline
\end{tabular}

Table III - In Vitro Release Data

\begin{tabular}{|c|c|c|c|c|c|c|c|c|}
\hline \multirow[t]{2}{*}{ Time (h) } & \multicolumn{8}{|c|}{ Amount released (\%) } \\
\hline & $m(n=3)$ & $\pm S$ & $m(n=3)$ & $\pm S$ & $m(n=3)$ & $\pm S$ & $m(n=3)$ & $\pm s$ \\
\hline 0 & 0.0 & 0.0 & 0.0 & 0.0 & 0.00 & 0.00 & 0.00 & 0.00 \\
\hline 1 & 7.6 & 1.2 & 8.6 & 1.6 & 5.9 & 0.3 & 6.5 & 0.7 \\
\hline 4 & 12.6 & 1.3 & 13.3 & 1.6 & 9.8 & 0.2 & 10.0 & 0.4 \\
\hline 5 & 14.3 & 1.2 & 14.9 & 1.6 & 11.1 & 0.1 & 11.1 & 0.3 \\
\hline 6.3 & 15.8 & 1.1 & 16.8 & 1.7 & & & & \\
\hline 6.5 & & & & & 13.1 & 0.1 & 13.2 & 0.2 \\
\hline 7 & 18.1 & 1.3 & 18.2 & 1.9 & 13.5 & 0.1 & 13.6 & 0.2 \\
\hline 8.5 & & & & & 14.8 & 0.1 & 14.9 & 0.3 \\
\hline 26 & & & & & 26.1 & 0.2 & 28.6 & 3.7 \\
\hline 26.3 & 40.3 & 1.1 & 37.6 & 2.5 & & & & \\
\hline 50 & 62.9 & 3.4 & 56.9 & 3.5 & & & & \\
\hline 64 & & & & & 43.5 & 1.2 & 49.5 & 5.3 \\
\hline 70.5 & 80.4 & 0.9 & 73.4 & 4.3 & & & & \\
\hline
\end{tabular}




\section{DISCUSSION}

The choice of polymer is an important factor since it should be biocompatible and have storage capacity for fair amount of the drug to be used. The copolymer of polylactide-coglycolic acid (PLGA) was chosen because each gram can store up to $0.8 \mathrm{~g}$ of bupivacaine and it is biodegradable ${ }^{9}$. Unlike the polyactide acid (PLA) polymer that can store only $22 \%$ of local anesthetic, which can make its production in industrial scale impracticable ${ }^{7}$.

The ideal rate between the local anesthetic and the polymer is between $55 \%$ and $75 \%$, because a concentration above this level is not associated with more prolonged blockade ${ }^{9}$. In the present study, the relationship between $50 \%$ enantiomeric excess bupivacaine and PLGA was 40-60, respecting the formulation values found in the literature. The amount of local anesthetic released from the microspheres is critical to assure an adequate neural block, requiring that the slow release maintain the therapeutic concentration before its elimination ${ }^{10}$.

The amount of local anesthetic incorporated to the microspheres in the present study was very close to the theoretical values, indicating that encapsulation by the spray-dryed method was efficient, in contrast with the low efficiency of encapsulation by methods that use evaporation or solvent extraction with some polymers ${ }^{7}$.

The kinetic profile of the in vitro release of $50 \%$ enantiomeric excess bupivacaine loaded microspheres followed a biphasic pattern, i.e., an initial increase followed by a phase of slow release. This profile was analyzed in two different $\mathrm{pHs}$, an acid, which would help the release of the contents of the microspheres and the other mimicking the human $\mathrm{pH}$ through the addition of a phosphate buffer to the solution. Comparing to bupivacaine-loaded microspheres prepared in a similar fashion, the initial increase was not significant, which can be justified by the small number (3) of samples analyzed in this process ${ }^{11}$. Despite of this, the results of the in vitro evaluation of the present study are in line with a prior study that predicted the release of $20 \%$ of the total content of bupivacaine in the first 24 hours, followed by the release of $7 \%$ of the content a day until the tenth day ${ }^{9}$. Microspheres are degraded in monomers that are metabolized through the Krebs cycle ${ }^{10}$.

It is possible to conclude that the manufacture of local anesthetic-loaded microspheres by emulsifying $50 \%$ enantiomeric excess bupivacaine with a polymer (PLGA), with elimination of the solvent through the spray-dryed method and lyophilization of the same is possible and it shows results similar to those of bupivacaine.

ACKNOWLEDGEMENTS: Laboratorio Cristalia for providing $50 \%$ enantimeric excess bupivacaine.

\section{REFERÊNCIAS - REFERENCES}

01. Borgeat A, Ekatodramis G, Schenker CA - Postoperative nausea and vomiting in regional anesthesia. A review. Anesthesiology, 2003;98:530-547.
02. Mulroy MF, Larkin KL, Batra MS et al. - Femoral nerve block with $0,25 \%$ or $0,5 \%$ bupivacaine improves postoperative analgesia following outpatient arthroscopy anterior cruciate ligament repair. Reg Anesth Pain Med, 2001;26:24-29.

03. Neal JM, Hebl JR, Gerancher JC et al. - Brachial plexus anesthesia: Essentials of our current understanding. Reg Anesth Pain Med, 2002;27:402-428.

04. Blanco MD, Bernardo MV, Gomez C et al. - Bupivacaine-loaded comatrix formed by albumin microspheres included in a poly (lactide-co-glycolide) film: in vivo biocompatibility and drug release studies. Biomaterials, 1999;20:1919-1924.

05. Araújo DR, Pinto LM, Braga AFA et al. - Formulações de anestésicos locais de liberação prolongada: Aplicações terapêuticas. Rev Bras Anestesiol, 2003;53:663-671.

06. Araújo DR, Fraceto LF, Braga AFA et al. - Sistemas de liberação controlada com bupivacaína racêmica (S50-R50) e mistura enantiomérica de bupivacaína (S75-R25): Efeitos da complexação com ciclodextrinas no bloqueio do nervo ciático em camundongos. Rev Bras Anestesiol, 2005;55:316-328.

07. Le Corre P, Le Guevello P, Gajan V et al. - Preparation and characterization of bupivacaine-loaded polylactide and polylactideco-glycolide microspheres. Int J Pharm, 1994;107:41-49.

08. Le Guevello P, Le Corre P, Chevanne F et al. — High-performance liquid chromatographic determination of bupivacaine in plasma samples for biopharmaceutical studies and applications to seven other local anesthetics. J Chromatogr, 1993;622:284-290.

09. Curley J, Castillo J, Hotz J et al. - Prolonged regional nerve block. Injectable biodegradable bupivacaine - polyester microspheres. Anesthesiology, 1996;84:1401-1410.

10. Malinovsky JM, Bernard JM, Le Corre P et al. — Motor and blood pressure effects of epidural sustained-release bupivacaine from polymer microspheres: A dose-response study in rabbits. Anesth Analg, 1995;81:519-524.

11. Le Corre P, Estebe JP, Clement R et al. - Spray-dryed bupivacaine-loaded microspheres: in vitro evaluation and biopharmaceutics of bupivacaine following brachial plexus administration in sheep. Int J Pharm, 2002;238:191-203.

\section{RESUMEN}

Tanaka PP, Estèbe JP, Campos R, Chevanne F, Le Corre P, Tenório SB, Torres MF — Preparación, Caracterización y Evaluación in Vitro de Microesferas de Bupivacaina en Exceso Enantiomérico de $50 \%$ (S75-R25).

JUSTIFICATIVA Y OBJETIVOS: Las micro esferas pueden ser utilizadas como un sistema de liberación controlada para prolongar la acción de anestésicos locales. Este estudio tuvo como objetivo la preparación, caracterización y el análisis de la liberación in vitro de micro esferas de bupivacaina en exceso enantiomérico de $50 \%(S 75-R 25)$.

MÉTODO: Las micro partículas fueron preparadas utilizando el copolímero de ácido poliláctico-co-glicólico con bupivacaina en exceso enantiomérico de un $50 \%$ por el método spray-dryed.

RESULTADOS: La caracterización de las micro esferas con relación a su tamaño y contenido fueron similares a los valores teóricos. La liberación in vitro presentó un estándar bifásico.

CONCLUSIONES: El proceso de fabricación de micro esferas con bupivacaina en exceso enantiomérico de $50 \%$ por el método spraydryed se puede realizar con resultados semejantes a los encontrados con micro esferas de bupivacaina. 